\title{
SCHLICK V. PENN-DIXIE CEMENT CORP: FRAUDULENT MISMANAGEMENT INDEPENDENT OF MISREPRESENTATION OR NONDISCLOSURE VIOLATES RULE 10b-5
}

With its decision in Schlick v. Penn-Dixie Cement Corp., ${ }^{1}$ the Second Circuit has reopened the extensive debate over the scope of section 10(b) of the Securities Exchange Act of $1934,{ }^{2}$ and in particular rule $10 \mathrm{~b}-5,{ }^{8}$ by upholding a claim under rule $10 \mathrm{~b}-5$ based on alleged fraudulent mismanagement, independent of misrepresentation or nondisclosure. In so doing it has given added support to those commentators who argue that the literal language of rule $10 \mathrm{~b}-5$ encompasses any scheme or transaction which tends to defraud shareholders in connection with the purchase or sale of securities.

While the applicability of rule $10 \mathrm{~b}-5$ to instances of misrepresentation or nondisclosure to investors in the trading markets has been historically firmly established, only within the last decade have courts upheld investor claims nnder the rule involving abuse of power by directors or controlling shareholders. The origin of this more modern view is generally credited to the Second Circuit in Schoenbaum v. Firstbrook, ${ }^{4}$ and its development has been traced in later cases. ${ }^{5}$ The development was apparently curtailed, however, by the same court's hold-

1. 507 F.2d 374 (2d Cir. 1974), petition for rehearing and rehearing en banc denied, (Dec. 27, 1974); petition for cert. filed, 43 U.S.L.W. 3502 (U.S. Mar. 13, 1975) (No. 74-1155).

2. 15 U.S.C. \& 78j(b) (1970).

3. 17 C.F.R. $\& 240.10$ b-5 (1974). The rule provides:

It shall be unlawful for any person, directly or indirectly, by use of any means or instrumentality of interstate commerce, or of the mails or of any facility of any national securities exchange,

(a) To einploy any device, scheme, or artifice to defraud,

(b) To make any untrue statement of a material fact or to omit to state a material fact necessary in order to make the statements made, in the light of the circumstances under which they were made, not misleading, or

(c) To engage in any act, practice, or course of business which operates or would operate as a fraud or deceit upon any person,

in connection with the purchase or sale of any security.

4. 405 F.2d 215 (2d Cir. 1968), rev'g 405 F.2d 200, cert. denied, 395 U.S. 906 (1969); Note, The Controlling Influence Standard in Rule 10b-5 Corporate Mismanagement Cases, 86 HaRv. L. Rev. 1007 (1973). See generally R. Jennings \& H. MarsH, Securrties Regulation-Cases aNd Materials 1223-30 (3d ed. 1972).

5. See text accompanying notes 33-41 infra. 
ing, in Popkin v. Bishop, ${ }^{6}$ that the "key issue" in a rule 10b-5 cause of action is an allegation of deception or nondisclosure, at least where the alleged corporate misdealing is dependent on or subject to shareholder ratification. ${ }^{7}$

The Popkin decision did not deter those commentators who contended that rule $10 \mathrm{~b}-5$ should, by its terms, be read to protect minority shareholders from breaches of the duty of loyalty by controlling shareholders and directors. In one important imstance their recommendations induced a major (albeit grudging) revision in the proposed Federal Securities Code to reflect the position that, despite Popkin, the question was still unresolved. ${ }^{8}$ Their arguments were reinforced by Schlick, in which another panel of the Second Circuit, on facts similar to those in Popkin, reached the opposite conclusion.

\section{The Decision IN Schlick}

The plaintiff in Schlick, a minority shareholder of Continental Steel Corp., an Indiana corporation, sued for damages allegedly suffered when Continental was inerged into a wholly-owned subsidiary of the defendant, Pemi-Dixie Cement Corp. The merger was accom-

6. 464 F.2d 714 (2d Cir. 1972).

7. Id. at 719-20. See also text accompanying notes $49-52$ infra.

8. Compare ALI FED. SEC. CODE $\$ 225$, Comment 3(b) (Tent. Draft No. 2, 1973) with ALI FED. SEC. CODE $\$ 1303$, Comment 5(c) (Reporter's Revision of Text of Tent. Drafts Nos. 1-3, 1974). Comment 3(b) reads, in pertinent part:

Although it has become almost trite to observe that the present statutory scheme, particularly by means of Rule 10b-5 and the proxy rules, has developed a considerable body of "federal corporation law," the Code, after all, is not designed to be a federal corporation law in the classic sense. And, outside the area of positive disclosure requirements through the registration and reporting processes, it is not easy to justify the federal policing of corporate mismanagement generally just because the particular "shenanigan" happens to involve a security. ... .

Even so, $\$ 225$ (c) makes it clear that company mismanagement may be a "deceptive act."

Comment $5(\mathrm{c})$, contained in the most recent revision, reveals the subtle but significant change in attitude toward rule $10 \mathrm{~b}-5$ :

It has been suggested by a number of commentators that Schoenbaum $v$. Firstbrook, ... . stands for the proposition that inadequate (some would say "grossly unfair") price coupled with controlling influence establishes a 10b5 violation regardless of disclosure. ... . On the other hand, it is possible to rationalize that case on the basis of the parent buyer's nondisclosure of an oil strike to "the corporation" as represented by the stockholders in the absence of a disinterested majority of directors. The opinion was so read by a panel of the same court in Popkin v. Bishop ...., where the court assumed that the allegedly unfair exchange ratio had been fully disclosed to the stockholders in the course of soliciting their required approval.

Although there may not be too much difference in end result, whichever theory is followed, and although most of the nondisclosure cases have involved Clause (2) of Rule $10 \mathrm{~b}-5$...., the fact remains that there are two other clauses that speak in terms of a fraudulent "act" or "scheme". . . .

Here again, the Code leaves the courts free to develop the unfair-pricecum-influence approach if they like or to hew to more traditional concepts of nondisclosure if they prefer. 
plished in literal compliance with the applicable state law, ${ }^{9}$ pursuant to a shareholder vote. Simce the parent corporation controlled 52.9 percent of the outstanding sliares, a sufficient number to assure approval of the transaction, it was in a position to dictate the exchange ratios despite the ritual of shareholder approval.

The first of four causes of action set forth in the complaint alleged a violation of section $10(\mathrm{~b})$ and rule $10 \mathrm{~b}-5$ : that the defendant engaged "in a course of business which operated as a fraud and deceit on the purchasers and holders of Continental stock."10 Specifically, the plaintiff accused Penn-Dixie of acquiring voting and inanagement control over Continental and using that control to manipulate and depress the value of Continental stock, in relation to Penn-Dixie stock, by using Continental's assets for the benefit of Penn-Dixie. ${ }^{11} \mathrm{He}$ further alleged that the defendant had caused the Continental pension fund to purchase Penn-Dixie stock in order to inflate its price. ${ }^{12}$ The second count alleged a violation of rule $14 a-9,{ }^{13}$ in that the proxy statement mailed to shareholders prior to the vote failed to disclose the sclieme. The third and fourth causes of action were pendent state law claims.

The district court interpreted the complaint as one based essentially on an unfair exchange ratio and, finding no damage caused by the alleged misrepresentations and nondisclosure, dismissed all counts, conceding that the complaint might have stated a cause of action under state law. ${ }^{14}$ Dismissal of the rule 10b-5 cause of action was predicated on its dependence upon proof of the allegations of material proxy statement omissions under the rule $14 \mathrm{a}-9$ claim..$^{15}$

On appeal, the three-judge pane ${ }^{16}$ reversed on all counts, empha-

9. 507 F.2d at 376 n.3. Under Indiana law, a majority vote of the outstanding shares of a corporation is sufficient to secure shareholder approval of a merger. IND. Stat. ANN. tit. 23, art. I, ch. 5, $\$ 2$ (b) (Burns 1972).

10. $507 \mathrm{~F} .2 \mathrm{~d}$ at 378 .

11. Id. at $376-77$.

12. Id. at 379 .

13. 17 C.F.R. $\$ 240.14 a-9$ (1974). In the final portion of its decision, the court in Schlick found that the allegation of material omissions in the proxy statement stated a cause of action under rule 14a-9, despite the fact that the parent corporation itself controlled a sufficient number of votes to approve the merger. As a result, Schlick has answered affirmatively the causation question left undecided by the Supreme Court in Mills v. Electric Auto-Lite Co., 396 U.S. 375, 385 n.7 (1970). Discussion of this issue is beyond the scope of this Note.

14. Schlick v. Penn-Dixie Cement Corp., [1973 Transfer Binder] CCH FEd. Sec. L. REP. \ 94,163 (S.D.N.Y. 1973).

15. Id. at 94,724 .

16. Only one circuit judge, Judge Oakes, sat on the three-judge panel in Schlick; the other members were two district court judges sitting by designation. This should not be taken to weaken Schlick's precedential effect, however, since a petition for rehearing and rehearing en banc failed to receive a single affirmative vote. See note 1 supra. 
sizing its disagreement with the lower court's characterization of the interrelation between the rule $10 \mathrm{~b}-5$ and rule $14 \mathrm{a}-9$ claims. ${ }^{17}$ In finding a basis for the rule 10b-5 claim independent of and more mclusive than the alleged proxy omissions, Schlick appears to have eroded the restrictive interpretation of the scope of rule 10b-5 imposed by Popkin.

The alleged course of conduct that formed the basis for the rule 10b-5 claim in Schlick amounted essentially to blatant insider conflict of interest and abuse of controlling influence. Under earlier statements by the Second Circuit, emanating from Birnbaum v. Newport Steel Corp. ${ }^{18}$ and O'Neill v. Maytag, ${ }^{19}$ such allegations of fraudulent corporate mismanagement were not actionable under rule $10 \mathrm{~b}-5 .{ }^{20}$ The court in Schlick authoritatively "puts to rest" the strictures imposed by Birnbaum, relying on the rationale of cases imposing liability for fraudulent corporate mismanagement ${ }^{21}$ under the plain language of rule $10 \mathrm{~b}-5$, despite the possible existence of a parallel remedy at state law. ${ }^{22}$

The Schlick opimion particularly emphasized that the market manipulation and the merger itself were the integral parts of the alleged scheme to defraud on which the rule $10 \mathrm{~b}-5$ claim was based. Although plaintiff also claimed misrepresentations and omissions in the proxy statement, the court held that they had significance under rule $10 \mathrm{~b}-5$ only as one independent aspect of the scheme. ${ }^{23}$ For this reason the court further held that the plaintiff should be subject to a less rigorous burden of proof on the issue of causation than would have been the case had his claims been grounded solely on allegations of misrepresentation or nondisclosure. ${ }^{24}$

\section{Development of the 10b-5 CaUSe of ACTION FOR FraUdULENT MISMANAGEMENT}

The attempt to restrict the scope of rule 10b-5 to instances of misrepresentation or nondisclosure originated in the same case that limited

17. 507 F.2d at 380 .

18. 193 F.2d 461 (2d Cir.), cert. denied, 343 U.S. 956 (1952).

19. 339 F.2d 764 (2d Cir. 1964).

20. E.g., Birnbaum v. Newport Steel Corp., 193 F.2d 461, 464 (2d Cir.), cert. denied, 343 U.S. 956 (1952).

21. E.g., Superintendent of Ins. v. Bankers Life \& Cas. Co., 404 U.S. 6 (1971); Schoenbaum v. Firstbrook, 405 F.2d 215 (2d Cir. 1968), rev'g 405 F.2d 200, cert. de nied, 395 U.S. 906 (1969). See also A.T. Brod \& Co. v. Perlow, 375 F.2d 393 (2d Cir. 1967).

22. 507 F.2d at 379-80, quoting Popkin v. Bishop, 464 F.2d 714, 718 (2d Cir. 1972).

23. 507 F.2d at 381 .

24. Id. at $380-81$. In a concurring opinion, Judge Frankel objected to the use of "loss causation" and "transaction causation" terminology in this aspect of the court's opinion. Id. at 384. 
its remedy to defrauded purchasers or sellers, Birnbaum v. Newport Steel Corp. ${ }^{25}$ In Birnbaum the Second Circuit construed rule 10b-5 as applying solely to fraudulent conduct perpetrated strictly within the trading market; it precluded challenges against corporate mismanagement or abuse of controlling influence under federal law. ${ }^{28}$ The unspoken premise in Birnbaum was that shareholders defrauded in corporate transactions which occurred beyond the pale of the securities trading market could effectively vindicate their rights in actions under applicable state corporate law. This philosophy became more firmly entrenched as a result of the Second Circuit's opmion in O'Neill v. Maytag, ${ }^{27}$ where a rule $10 \mathrm{~b}-5$ action based upon alleged breach of fiduciary duty by corporate directors was dismissed because the entire board of directors was allegedly implicated and therefore no "deception" was involved. ${ }^{28}$

In Schoenbaum v. Firstbrook ${ }^{29}$ the Second Circuit overruled its restrictive interpretation in $O^{\prime} N e i l l$ of the scope of the rule $10 \mathrm{~b}-5$ remedy, recognizing for the first time that the fraudulent exercise of controlling corporate influence could be actionable under federal law. ${ }^{30}$ Schoenbaum was also the first case to acknowledge a cause of action grounded on a subdivision of rule $10 \mathrm{~b}-5$ other than subdivision (b) in the context of an alleged abuse of control. ${ }^{31}$ There was dictum in Schoenbaum, however, regarding alleged misrepresentations made to shareholders as an integral part of the fraudulent scheme; ${ }^{.22}$ this dictum,

25. 193 F.2d 461 (2d Cir.), cert. denied, 343 U.S. 956 (1952).

26. Id. at 464 .

27. 339 F.2d 764 (2d Cir. 1964).

28. Id. at 767-68. The $O$ 'Neill rationale has not been well received in other circuits. See, e.g., Pappas v. Moss, 393 F.2d 865 (3d Cir. 1968); Dasho v. Susquehanna Corp., 380 F.2d 262 (7th Cir.), cert. denied, 389 U.S. 977 (1967). See also R. JENnings \& H. Marsh, SeCurities Regulation-Cases and Materials 1225-26 (3d ed. 1972).

29. 405 F.2d 215 (2d Cir. 1968), rev'g 405 F.2d 200, cert. denied, 395 U.S. 906 (1969).

30. See also Shell v. Hensley, 430 F.2d 819 (5th Cir. 1970); Rekant v. Desser, 425 F.2d 872 (5th Cir. 1970).

31. 405 F.2d at 219-20. In an earlier decision, A.T. Brod \& Co. v. Perlow, 375 F.2d 393 (2d Cir. 1967), the court upheld a cause of action by a stockbroker alleging that the defendant had engaged in a scheme of ordering shares and paying for them only if the value increased. In a significant paragraph the court stated:

We believe that $\S 10(\mathrm{~b})$ and Rule $10 \mathrm{~b}-5$ prohibit all fraudulent schemes in connection with the purchase or sale of securities, whether the artifices employed involve a garden type variety of fraud, or present a unique form of deception. Novel or atypical methods should not provide immunity from the securities laws.

Id. at 397. See also Trussell v. United Underwriters, Ltd., 228 F. Supp. 757 (D. Colo. 1964), and Cochran v. Channing Corp., 211 F. Supp. 239 (S.D.N.Y. 1962), which discuss the distinctions between the three subdivisions but decide on the basis of subdivision (b).

32. 405 F.2d at 220. 
together with the fact that the case dealt with fraudulent issuer activities in the trading market, left a residue of ambiguity regarding the thrust of the court's holding.

Since the Schoenbaum decision the Supreme Court has twice addressed the distinctions among the subdivisions of rule 10b-5. Neither decision, unfortunately, dispels the ambiguity left by Schoenbaum, since the disposition of both cases rehed to an unascertainable extent on an allegation of material misrepresentation or omission as a significant element of the rule $10 \mathrm{~b}-5$ claim.

In Superintendent of Insurance v. Bankers Life \& Casualty Co.. ${ }^{88}$ the Supreme Court upheld the sufficiency of a rule $10 \mathrm{~b}-5$ claim that alleged a course of conduct which amounted to a breach of fiduciary duty by corporate insiders: depletion of corporate assets, in connection with securities transactions, to the detriment of corporate creditors. Seeking dismissal of the complaint, the defendant contended that the challenged transactions amounted at most to misappropriation and that rule $10 \mathrm{~b}-5$ was not applicable. In rejecting this argument, Justice Douglas stated:

The Congress made clear that "disregard of trust relationships by those whom the law would regard as fiduciaries, are all a seamless web" along with mamipulation, investor's ignorance, and the like. ... Hence we do not read $\$ 10(\mathrm{~b})$ as narrowly as the Court of Appeals; it is not "limited to preserving the integrity of the securities markets". . . , though that purpose is included. Section 10(b) must be read flexibly, not technically and restrictively. ${ }^{34}$

Under the most likely reading of Bankers Life, the Court has implicitly recognized certain breaches of fiduciary duty, independent of alleged misrepresentation or nondisclosure, as a species of fraud within the ambit of the rule. The Court's concession of the inapplicability of section 10(b) to "transactions which constitute no more than internal corporate mismanagement" ${ }^{35}$ is consistent with such an interpretation, if in this context "corporate mismanagement" is interpreted as meaning breaches of the common law duty of care by directors or officers. While shareholders with such complaints may be relegated to remedies under state corporate $1 \mathrm{aw},{ }^{36}$ challenges to that type of insider action "in connection with" the purchase or sale of a security which constitutes fraud-that is, a breach of the duty of loyalty-can be redressed under section 10(b), "whatever might be available as a remedy under state law."37

33. 404 U.S. 6 (1971).

34. Id. at 11-12.

35. Id. at 12.

36. See text accompanying note 79 infra.

37. 404 U.S. at 12. 
In Affiliated Ute Citizens of Utah v. United States, ${ }^{38}$ the Supreme Court again commented on the distinct scope and applicability of the three subdivisions of rule $10 \mathrm{~b}-5$ in the context of both misrepresentations and fraudulent transactions independent of misrepresentation. In reversing the lower court determination, a unanimous court implied that defendants would be liable under the first and third subdivisions of rule $10 \mathrm{~b}-5$, regardless of misrepresentation, where a transaction or course of business by parties with controlling influence operated as a fraud upon shareholders. ${ }^{39}$ But just as the Second Circuit did in Schoenbaum, ${ }^{40}$ the Court in Affiliated Ute blunted the thrust of its holding on this point by reversing the lower court on the question of fraudulent misrepresentation as well. ${ }^{41}$

The Second Circuit in Popkin v. Bishop ${ }^{42}$ attempted to close the gap left by Schoenbaum, Bankers Life, and Affiliated Ute. In a unanimous decision the court held that the plaintiff's failure to plead a inisrepresentation or material omission was fatal to a cause of action under rule 10b-5. ${ }^{43}$ In Popkin, a shareholder sued to enjoin the merger of his corporation and its two subsidiaries into another corporation that owned 51.7 percent of the first corporation. Plaintiff conceded that the proxy statement issued prior to the shareholder vote on the merger proposal made a full and fair disclosure; ${ }^{44}$ he based his suit on the grossly unfair exchange ratio proposed by the controlling shareholder as a term of the merger. Alleging a course of conduct by the majority shareholder which amounted to self-dealing and fiduciary breach, the shareholder contended that rule $10 \mathrm{~b}-5$ was meant to be more than merely a disclosure provision; he argued that the rule afforded oppressed minority shareholders protection against overreaching and selfdealing by those in control whether or not there was full disclosure. ${ }^{45}$

Despite the rationale of Schoenbaum and subsequent cases, ${ }^{46}$ the court in Popkin dismissed the rule 10b-5 complaint. As a premise for

38. 406 U.S. 128 (1972).

39. Id. at 152-53.

40. See text accompanying note 32 supra.

41. 406 U.S. at 152-53.

42. 464 F.2d 714 (2d Cir. 1972).

43. Id. at 718,720 .

44. Id. at 718 .

45. Id.

46. E.g., Drachman v. Harvey, 453 F.2d 736 (2d Cir. 1972) (en banc), rev'g 453 F.2d 722 (2d Cir. 1971). Drachman held that the sale of controlling influence by a majority shareholder as part of a conspiracy to cause the corporation to improvidently redeem its debtentures constituted a rule 10b-5 violation. Iu its earlier panel decision, the court had voted 2-1 to dismiss the complaint, based on its own decision in Superintendent of Ins. v. Bankers Life \& Cas. Co., 430 F.2d 355 (2d Cir. 1970), rev'd, 404 U.S. 6 (1971). The en banc reversal in Drachman followed the Supreme Court's reversal of Bankers Life. 
its holding, the court distinguished Schoenbaum on several grounds. It first noted that, although Schoenbaum had suggested that improper self-dealing itself constituted a violation of rule $10 \mathrm{~b}-5,{ }^{47}$ the conclusion was implicitly qualified by language indicating liability for misrepresentation as well. ${ }^{48}$ In addition, the court differentiated corporate selfdealing transactions requiring shareholder approval under state law from those transactions in which shareholder approval is not mandated by statute. ${ }^{49}$ It argued that where the action of the board of directors is not subject to review by shareholders, the judicial inquiry should focus on the fiduciary fairness of the directors' actions, either because no disclosure need be made to shareholders for authorization of the proposed action or because such disclosure does not occur until shareholders are powerless to interrupt the adopted actions. ${ }^{60}$ Under this rationale, actions authorized exclusively by the board, as in Schoenbaum, may be actionable under rule $10 \mathrm{~b}-5$, regardless of the quality and scope of disclosure, when it is claimed that they adversely affect shareholder interests. Such actions could include issuance of shares, stock splits, reverse stock splits, and short-form mergers, among others. ${ }^{51}$ Conversely, the court implied in Popkin that corporate structural changes subject to shareholder vote-such as sales of assets, longform mergers, and dissolutions-are not remediable under rule 10b-5 if there has been full disclosure, irrespective of blatant economic or equitable unfairness. ${ }^{52}$

Two implicit assumptions underlie this distinction. The first is that exposure of a proposed corporate transaction to shareholder scrutiny and approval will somehow purify and legitimate conduct which otherwise would smack of self-dealing or abuse of controlling influence. The second is that state law will provide an adequate alternative to any federal remedy when full disclosure of inequitable terms forces shareholders to resort to state remedies to enjoin or rescind the corporate action. ${ }^{53}$

The validity of these assumptions is suspect and the court's reh-

47. Schoenbaum v. Firstbrook, 405 F.2d 215, 219-20 (2d Cir. 1968), cert. denled, 395 U.S. 906 (1969).

48. Id. at 220 .

49. 464 F.2d at 719,720 .

50. Id. at 719.

51. "Going private," a current phenomenon in the business community, has rekindled interest in these corporate structural changes as attractive devices for eliminating minority shareholders. As a result of such corporate action, the issuer may be able to repurchase its own publicly-held shares. By reducing the total number of shareholders, a publicly-held corporation may evade federal regulation under the Securities Exchange Act of 1934. See Address by A.A. Sommer, Jr., Commissioner of the SEC, in CCH FED. SEC. L. REP. Tा 80,010 (1974).

52. 464 F.2d at 720.

53. Id. 
ance on them is responsible for the heavy criticism of the decision. ${ }^{54}$ The imeffectiveness of shareholder review as a curb on abuse by the majority in any situation has been well documented. ${ }^{65}$ The danger of fraudulent activity is even more apparent in parent-subsidiary situations, such as in Popkin and Schlick, where the proponent of the transaction controls either sufficient votes to assure outright approval of the proposal or a large enough bloc to control proxy machinery and dictate management policy. Although in this latter situation the possibility exists that fear of shareholder rejection of the proposal might induce management to sweeten the economics or the equities of the proposed plan, its control over vital proxy machinery typically makes such a benevolent gesture unnecessary. ${ }^{56}$ The practical result in situations such as those complained of in Popkin and Schlick is that incumbent management has free reign to propose the transaction and its terms, and then to authorize the action in the name of the shareholders.

The assumption that the injured shareholders have an adequate state remedy is equally illusory. While the court states that the Delaware forum could provide rehef from conduct which constituted selfdealing or fiduciary breach, most jurisdictions review the equitable issue of fiduciary fairness solely in terms of economic valuation of dissenting shares and pay only lip service to equitable fiduciary standards. $^{57}$ In this connection it is iromic, but not coincidental, that the effect of the decision cited by the court in Popkin to justify its assertion of adequate state remedies was to uphold the validity of exculpatory clauses in Delaware certificates of imcorporation and to deny the plaintiff injunctive relief. ${ }^{58}$

\section{Is NONDISCLOSURE STILL "KeY"? THE IMPACT OF Schlick ON Popkin}

The status of Popkin after the decision in Schlick is at least to some extent open to conjecture. Schlick did not claim to overrule Popkin; in fact, the court cited Popkin approvingly for the proposition

54. Brudney \& Chirelstein, Fair Shares in Corporate Mergers and Takeovers, 88 HaRv. L. REv. 297, 302-03 (1974); Jacobs, The Role of Securities Exchange Act Rule 10b-5 in the Regulation of Corporate Mismanagement, 59 CoRnell L. Rev. 27, 7273, 88-92 (1973); Note, The Controlling Influence Standard in Rule 10b-5 Corporate Mismanagement Cases, 86 HARv. L. REv. 1007 (1973).

55. See Brudney \& Chirelstein, supra note 54; Eisenberg, The Legal Roles of Shareholders and Management in Modern Corporate Decision Making, 57 CaLIF. L. Rev. 1 (1969); Manning, The Shareholder's Appraisal Remedy: An Essay for Frank Coker, 72 YALE L.J. 223 (1962).

56. See Brudney \& Chirelstein, supra note 54, at 299-300; Eisenberg, supra note 55, at 23-43; Manning, supra note 55, at 229.

57. See Brudney \& Chirelstein, supra note 54, at 309-13, and cases cited therein.

58. Sterling v. Mayflower Hotel Corp., 33 Del. Ch. 293, 93 A.2d 107 (1952). 
that the defendant cannot cut off the plaintiff's federal remedy simply by asserting that the allegations amount to "just" corporate mismanagement. ${ }^{50}$ And simce Schlick reversed the district court on two issuesthe question of material omissions in the proxy statement under the rule 14a-9 clain as well as the rule $10 \mathrm{~b}-5$ claim-the decision could be read as falling within the ambit of Schoenbaum without weakening the thrust of Popkin.

Such a reading, however, would ignore the careful and independent emphasis devoted in Schlick to the rule 10b-5 claim completely apart from the question of material omissions. Given this independent treatment, it is clear that Popkin's characterizaton of "nondisclosure as a key issue in Rule 10b-5 cases" ${ }^{60}$ has been undercut. ${ }^{61}$

It may be argued that Popkin and Schlick can be distinguished on the basis of their pleadings. But such an attempt would be fruitless, since the typical plaintiff complaining of such a transaction will be able to allege either a scheme to defraud the minority shareholders or a failure to disclose a "grossly inadequate" exchange ratio. ${ }^{62}$ This was conceded by the court in Popkin ${ }^{63}$ and borne out in the subsequent history of that litigation. ${ }^{84}$

Another atteinpt to reconcile the two decisions and to restrain the implications of Schlick on the use of rule 10b-5 might focus on the remedies pursued in each case. Popkin was an attempt to enjom a

59. 507 F.2d at $379-80$.

60. $464 \mathrm{F.2d}$ at 719.

61. Popkin may survive as requiring an allegation of misrepresentation or omission in order to avoid dismissal of a complaint. Although the Second Circuit in a footnote to Popkin, disclaimed a holding that failure to allege non-disclosure would itself justify dismissal of a complaint challenging a merger transaction under rule 10b-5 (464 F.2d at 720 n.17), it dismissed the Popkin complaint because the record indicated full d'sclosure had been made. Nevertheless, in Popkin v. Wheelabrator-Frye, Inc., [1973 Transfer Binder] CCH FED. SEC. L. REP. II 94,091 (S.D.N.Y. 1973), the district court denied a motion to dismiss after the plaintiff in Popkin v. Bishop redrafted his complaint to allege defendant's failure to disclose, inter alia, the adverse effects of the unfair exchange ratios. On a more narrow ground, then, Popkin stands as a warning to counsel not to concede or stipulate to full and fair disclosure. 464 F.2d at 718, 720 .

62. In this regard, it should be noted that, in their petition for rehearing, the defendants in Schlick contended that the Schlick decision had overruled Segal v. Gordon, 467 F.2d 602 (2d Cir. 1972). Defendants-Appellees Petition for Rehearing at 9-12. Segal held that rule 9 (b) of the Federal Rules of Civil Procedure, which requires that fraud be pleaded with particularity, is applicable to rule $10 \mathrm{~b}-5$ causes of action. Tho court in Schlick found the specificity requirements imposed by Segal to be "without applicability to the case at hand." 507 F.2d at 380 n.10. It held that the requirement of rule 9 (b) may be satisfied where the allegations are accompanied by a statement of the facts upon which the belief is founded, noting further that the specificity requirement may appropriately be relaxed in shareholder suits regarding internal corporate affairs, where the facts constituting fraud are peculiarly within the opposing party's knowledge. 507 F.2d at 379.

63. 464 F.2d at 720 .

64. See note 61 supra. 
proposed merger in which the plaintiff's pleadings were cast in economic terms of "grossly inadequate" exchange ratios "as a matter of simple arithmetic." ${ }^{65}$ Schlick, on the other hand, involved a claim for damages, pleading conspiracy and fraud in the transactions that resulted in the merger. In cases where the defendant controls enough votes to approve a merger without help from the minority, it can be argued that undervaluation alone should not allow a recalcitrant shareholder to veto by injunction a merger he would otherwise be powerless to hinder; if not, the remedy would exceed the damages.

This argument, however, fails to consider the deterrent effect of an action to enjoin an unfair merger. It is unlikely that directors or controlling shareholders intent on defrauding minority shareholders would be greatly deterred by the knowledge that the minority could receive in court no more than the same fair offer management was duty bound to propose originally. ${ }^{B \theta}$ If, on the other hand, a minority shareholder could enlist a federal court's aid to halt the merger until a more equitable offer was made, management would be under pressure to make a fair proposal at the outset.

Lower courts in the Second Circuit have attempted to limit Popkin to transactions involving shareholder approval, and have continued to apply the Schoenbaum analysis in the absence of ratification. ${ }^{67}$ After Schlick this distinction is no longer important, for the conflict between Schlick and Popkin does not turn on whether the fraudulent transaction is subject to shareholder scrutiny and approval, but on the definition of "fraud" and the elements of a proper cause of action under rule 10b5. Even in its most restricted interpretation Schlick should be viewed as reopening this aspect of the rule to further case by case development.

There are persuasive arguments for lifting the strictures imposed by Popkin and returning to the emphasis on abuse of control influence reinstated by Schlick.

The first of these arguments is derived from the tripartite nature of rule 10b-5 itself. Subdivision (b) is patterned after the common law action for deceit, imposing liability for misrepresentation or misleading nondisclosure; ${ }^{68}$ subdivisions (a) and (c), on the other hand, speak somewhat ambiguously of "device, scheme, or artifice to de-

65. 464 F.2d at 717.

66. See, e.g., Jones v. H.F. Ahmanson \& Co., 1 Cal. 3d 93, 460 P.2d 464, 81 Cal. Rptr. 592 (1969).

67. See, e.g., Levine v. Biddle Sawyer Corp., 383 F. Supp. 618 (S.D.N.Y. 1974). In Levine, the court noted that the complaint sufficiently alleged misrepresentation and nondisclosure, yet nonetheless discussed the lack of shareholder ratification of the proposed action. Id. at 622 .

68. 17 C.F.R. $\$ 240.10$ b-5 (1974). See note 3 supra. 
fraud" most of the early rule $10 \mathrm{~b}-5$ cases there was a tendency to identify the term "fraud" with the action for deceit, and much litigation revolved around the common law elements of that cause of action. ${ }^{71}$ The result was a practice of indiscriminately construing all three subdivisions of the rule as coextensive.

This interpretation of rule $10 \mathrm{~b}-5$ is too limited, as other decisions more responsive to the multi-faceted settings of securities transactions have recognized. As the Supreme Court pointed out in a related context, at equity the term "fraud" has a nore encompassing range:

Fraud, indeed, in the sense of a court of equity properly includes all acts, omissions and concealments which involve a breach of legal or equitable duty, trust, or confidence, justly reposed, and are injurious to another, or by which an undue and unconscientious advantage is taken of another. ${ }^{22}$

Thus, purely as a matter of construction, rule $10 \mathrm{~b}-5$ should not be read as requiring misrepresentation or nondisclosure.

On a policy level, it can be strongly argued that extending federal protection to minority shareholders against breaches of fiduciary duty by controlling interests in connection with securities transactions is a logical exercise of the policies underlying federal securities regulation. If, as is often repeated, one of the purposes of federal regulation is to encourage the faith of public investors in the integrity of the market, then providing investors with a forum in which to seek redress for damages they might suffer seems an essential proposition.

Providing a federal forum is especially important where otherwise there nnay not be effective judicial review. In challenges to corporate structural changes, such as the mergers involved in Popkin and Schlick, depriving minority shareholders of a federal forum relegates the plaintiffs to state remedies that are typically neither adequate nor effectual. The court gave scant attention to this argument in Popkin. Indeed, in dismissing the plaintiff's rule $10 \mathrm{~b}-5$ cause of action, it stated that judicial review of the fairness of the transaction could be had under the "careful scrutiny" standard of Delaware law in a state court pro-

69. Id.

70. Id.

71. See, e.g., Trussell v. United Underwriters, Ltd., 228 F. Supp. 757 (D. Colo. 1964). The common law action of deceit requires a false representation, knowledge of its falsity, intent, reliance by the plaintiff, and damage. W. Prosser, LAw of TORTS 685-86 (4th ed. 1972).

72. SEC v. Capital Gains Research Bureau. Inc., 375 U.S. 180, 194 (1963). See also Superintendent of Ins, v. Bankers Life \& Cas. Co., 404 U.S. 6, 11-12; id. at 10 n.7 ('misrepresentation is a 'garden variety' type of fraud ..."); ALI FED. SEC. COog $\$$ 1303, Comment 5(c) (Reporter's Revision of Text of Tent. Drafts Nos. 1-3, 1974), reproduced in part at note 8 supra. 
ceeding, and that the scope of the federal injunctive remedy was at best coextensive with this state remedy. ${ }^{73}$ Under most interpretations, the utilization of such a standard of review would require management to demonstrate a high degree of fairness in the transaction, and would shift the procedural burden of proof on the question of fairness to the proponent of the transaction. ${ }^{74}$ Yet Delaware courts, in which many of these actions inust be brought, consistently neglect such a standard of review in many questions involving the fiduciary fairness of parentsubsidiary dealings, and have tended to give deferential approval to actions undertaken by the board of the parent corporation. ${ }^{75}$ Accordingly, Delaware courts currently require that the plaintiff demonstrate self-dealing, or palpable overreaching by the fiduciary, as a prerequisite to application of the "inherent fairness" standard to which Popkin refers. ${ }^{78}$

It is true that state law may furnish appraisal rights to shareholders dissenting from corporate structural changes, but this remedy is a poor substitute for the economic protection that would be afforded to the minority in a situation where arm's length negotiation was practiced. Appraisal rights have never taken into account the increase in value of the shares corresponding to the enhanced net worth of the surviving corporation in excess of the individual pre-merger net worth of the constituent corporations. ${ }^{77}$ Even the limited protection afforded by the

73. $464 \mathrm{~F} .2 \mathrm{~d}$ at 720. See text accompanying note 58 supra. The assessment in Popkin of the plaintiff's remedies under Delaware law is highly optimistic and can perhaps most charitably be credited to inexperience. Those federal courts which more frequently deal with Delaware law have not been so hopeful. See Langfelder v. Universal Laboratories, Inc., 163 F.2d 804, 808 (3d Cir. 1947); Barret v. Denver Tramway Corp., 53 F. Supp. 198, 205 (D. Del. 1943), aff'd, 146 F.2d 701 (3d Cir. 1944). See also Cary, Federalism and Corporate Law: Reflections upon Delaware, 83 YALE L.J. 663 (1974).

74. E.g., Sterling v. Mayflower Hotel Corp., 33 Del. Ch. 293, 93 A.2d 107 (1952).

75. A standard codified in some progressive states to regulate securities offered in transactions which might otherwise operate to the detriment of minority shareholders requires that the proponent demonstrate the "fair, just, and equitable" character of the proposed action. E.g., CAL. CoRP. CODE $\$ 25140$ (b) (West Supp. 1974); see Western Air Lines, Inc. v. Schutzbank, 258 Cal. App. 2d 218, 66 Cal. Rptr. 293 (2d Dist. 1968). This proposed standard was intentionally omitted from the Uniform Securities Act as being "too vague." See National Ass'n of Securities Adm'rs, Proceedings 73-76 (1956). The Uniform Securities Act is thoroughly criticized in Jennings, The Role of the States in Corporate Regulation and Investor Protection, 23 LAW \& CONTEMP. PROB. 193 (1958). Professor Jennings has also warned that the proposed Federal Securities Code may be "a counter-revolutionary effort to roll back federal securities regulation." Conference on Codification of the Federal Securities Laws, Proceedings, Codification-Civil Liability Under the Federal Securities Laws, 22 Bus. Law. 878, 882 (1967).

76. See, e.g., Sinclair Oil Corp. v. Levien, 280 A.2d 717 (Del. 1971); Getty Oil Co. v. Skelly Oil Co., 267 A.2d 883 (Del. 1970); Chasin v. Gluck, 282 A.2d 188 (Del. Ch. 1971).

77. See Brudney \& Chirelstein, supra note 54, at 313-25. 
appraisal right has been eliminated in many recent statutes in the case of corporations whose shares are listed on a national exchange. ${ }^{78}$

Thus it seems clear that the result afforded by Schlick-making available a federal forum to hear shareholder complaints alleging fraudulent effectuation of corporate structural changes-will enhance both the confidence of investors in the securities market and the likelihood that they will obtain redress should their confidence in a particular manageinent prove to have been sorely misplaced.

In reply, opponents of the application of rule 10b-5 to embrace mismanagement and abuse of controlling influence in conjunction with securities transactions generally urge that such an interpretation amounts to an invasion of the states' common law and statutory regulation of corporate management. If the decision is made to adopt a "federal corporation law," the argument continues, such a determination should be made by Congress and not by the courts. In addition, there is some judicial sentiment opposing expansion of the rule under what might be called the "floodgate theory." "79

These argunents ignore the internal limitation of the scope of rule 10b-5. The rule covers only acts done "in connection with the purchase or sale of any security." Even at its furthest extension, section 10 (b) protects primarily the market and those who enter it. Rule 10b-5 does not encompass those matters, appropriately governed by the business judgment rule, which involve the day-to-day running of the corporation by its officers, directors, or controlling shareholders. Issues such as waste due to negligence (as opposed to the fraudulent sale of securities), involving violation of the duty of care, are outside the purview of rule $10 \mathrm{~b}-5$, and a complaining shareholder must resort to state remedies. It is only when management's activities affect the

78. In Schlick, the plaintiff had no appraisal rights since the shares were nationally listed. IND. STAT. ANN. tit. 23, art. I, ch. $5 \$ 7$ (Burns 1972). As the court pointed out, this contributed to his damages:

The rationale of the statutory exception may well be that appraisal rights are not necessary where the shares of dissenting shareholders can be readily sold at a fair market price. But here, if the appellart's allegations are true, the purpose of the appraisal statute was thwarted as the market price of Continental shares had been manipulated so as not to reflect their true value.

507 F.2d at 377 n.6.

79. As Judge Medina expressed it:

This does indeed open the floodgates. For the result is to transform a simple cause of action against directors for waste or the use of bad judgment in the sale of corporate assets into a federal securities fraud case by judicial fiat. In my opinion the Congress never intended the Securities Exchange Act of 1934 to be interpreted so broadly as this.

Schoenbaum v. Firstbrook, 405 F.2d 215, 220 (2d Cir. 1968) (Medina, J., dissenting). And see Manor Drug Stores v. Blue Chip Stamps, 492 F.2d 136, 147 (9th Cir. 1973) (Hufstedler, J., dissenting). But cf. Eason v. General Motors Acceptance Corp., 490 F.2d 654, 660-61 (7th Cir. 1973), cert. denied, 416 U.S. 960 (1974). 
market for securities that the rule can serve as the basis for a federal cause of action.

Because the securities markets today encourage and assume a nationwide distribution of shareholdings, it is no longer feasible to rely on the states for effective regulation. Individual shareholders in California, for example, would be pragmatically discouraged from instituting an action in Delaware in an atteinpt to enjoin a proposed merger on facts similar to those presented in Schlick or Popkin. And their own state, which would have a greater interest in protecting them, might be unable for constitutional reasons to exercise its regulatory power over the foreign corporation. ${ }^{80}$ Moreover, the provisions for ease of venue and nationwide service of process in the federal law are essential to protect the interests of widely disbursed shareholders. ${ }^{81}$

In response to contentions that such an expansive interpretation of the federal regulatory scheme should be inade by Congress and not by the courts, it must be noted that section 10(b) was passed in its broad form precisely because Congress felt itself unable to make specific legislative proposals. It chose instead to delegate the responsibility to the Securities and Exchange Commission. ${ }^{82}$ The SEC has accepted this responsibility and does not appear to doubt its jurisdiction and competence to promulgate rules under section $10(\mathrm{~b})$ to control abusive securities transactions. ${ }^{83}$

80. California was among the first states to "look through" the domicile of the corporation to see which state was the most interested in regulating its securities transactions. Western Air Lines, Inc. v. Sobieski, 191 Cal. App. 2d 399, 12 Cal. Rptr. 719 (2d Dist. 1961). But to obviate constitutional problems, California requires that at least 25 percent of the corporation's shareholders be residents of California before the Department of Corporations can exercise its full regulatory powers over a foreign corporation's securities. CAL. CORP. CODE $\S 25103$ (b) (West Supp. 1974). California also exempts all securities listed on the New York and American stock exchanges. CAL. CORP. Code $\S 25100$ (o) (West Supp. 1974).

81. Securities Exchange Act of 1934 \& 27, 15 U.S.C. § 78aa (1970).

82. As Professor Jennings observed in 1967 :

Congress is absorbed with Vietnam. It is struggling with the problems of urban society, with air pollution and with the war on poverty. I submit that securities regulation does not have a very high priority. Furthermore, one of the bases of Section 10 of the Securities Exchange Act was that Congress simply did not know how to write a statute that would meet the complex problems in this area; they delegated to the Securities and Exchange Commission a broad rule-making power to prevent manipulative and deceptive devices and contrivances. It is not clear that Congress is disturbed by recent developments in this area; the unhappiness seems to be largely in other quarters.

Conference on Codification of the Federal Securities Laws, supra note 75, at 881 (Remarks of Professor Richard W. Jennings).

83. A recent example of SEC regulation of transactions involving potential abuse of control influence is embodied in a staff proposal for rules governing mergers for the purpose of "going private." SEC Securities Exchange Act Release No. 11,231 (Feb. 6, 1975), in CCH FED. SEC. L. REP. $\mid$ 80,104 (1975). (The "going private" phenomenon is discussed briefly at note 51 supra.) These rules have been proposed under section 13 (e) of the Securities Exchange Act of 1934, 15 U.S.C. \& 78m(e) (1970). The grant 
In short, there appear to be no convincing policy reasons against exercising federal regulation to the limit contemplated by the literal terms of the statute. The most common argunnent in opposition, the "states' rights" theory, first assumes, often erroneously, an effective state remedy. Second, this contention ignores the jurisdiction and venue limitations of state law that may further vitiate an often inadequate remedy. Finally, it fails to persuade that the directors of major corporations, fiduciaries for a national investor constitutency, should be governed when they deal in the securities markets solely by a standard of loyalty established by the Delaware legislature, or that of any other single state. ${ }^{84}$

\section{CONCLUSION}

In Schlick v. Penn-Dixie Cement Corp., the Second Circuit has once again embarked on the more sophisticated and responsive analysis of self-dealing and breach of trust by controlling interests that it origmated in Schoenbaum v. Firstbrook. In so doing, the court has undermined the atteinpt in Popkin v. Bishop to limit actionability under rule $10 \mathrm{~b}-5$ in allegedly fraudulent corporate structural changes to cases of misrepresentation and nondisclosure. While the thrust of Schlick arguably is softened by the disposition of the plaintiff's other claims based on material omissions and by the unusual composition of the panel, ${ }^{85}$ the decision evidences a disinclination to follow the reasoning of Popkin. In the wake of Schlick, courts are once again free to continue the case by case application of rule $10 \mathrm{~b}-5$ to alleged abuse of controlling influence, improper self dealing, and fiduciary breach. The construction of the rule itself, the protective policies which form its foundation, and the federal scheme for regulating the securities markets all suggest that the investors' interest will best be served by a judicial willingness to afford federal protection to shareholders, rather than by attempts to restrict federal jurisdiction, thereby relegating injured minority shareholders to nonexistent or inadequate remedies under state law.

Harold J. McElhinny*

\footnotetext{
of power to the SEC under this section is similar to that of section 10 , in that it allows the SEC to define and prevent "acts and practices which are fraudulent, deceptive, or manipulative" in connection with an issuer's purchase of its own equity securities. Id.

84. See Cary, supra note 73.

85. See note 16 supra.

* B.A. 1970, University of Santa Clara; third-year student, Boalt Hall School of Law.
} 